\title{
APAKAH KEPRIBADIAN, KEKOSMOPOLITAN, DAN ORIENTASI NILAI MENENTUKAN KUALITAS HIDUP SUBJEKTIF KELUARGA?
}

\author{
Olivia Sabrina ${ }^{1}$, Megawati Simanjuntak ${ }^{\left.1^{*}\right)}$ \\ ${ }^{1}$ Departemen IImu Keluarga dan Konsumen, Fakultas Ekologi Manusia, Insitut Pertanian Bogor, \\ Bogor 16680, Indonesia \\ ${ }^{*}$ E-mail: mega.juntakipb@gmail.com
}

\begin{abstract}
Abstrak
Kepribadian, kekosmopolitan, dan orientasi nilai dapat memengaruhi kualitas hidup keluarga yang menetap di kota. Tujuan penelitian ini adalah untuk menganalisis pengaruh kepribadian, kekosmopolitan, dan orientasi nilai terhadap kualitas hidup subjektif keluarga (personal dan sosial) di Kota Bogor, Provinsi Jawa Barat. Penelitian ini menggunakan desain cross sectional dan melibatkan 56 keluarga. Data dikumpulkan dengan wawancara pada istri menggunakan kuesioner. Selanjutnya, data dianalisis menggunakan uji korelasi Pearson dan uji regresi linear berganda. Hasil menunjukkan bahwa nilai keluarga, kesadaran dalam masyarakat, dan orientasi nilai memiliki hubungan yang positif signifikan dengan kualitas hidup subjektif keluarga dan dua dimensinya. Orientasi nilai tradisionalisme memiliki hubungan yang positif signifikan dengan kualitas hidup subjektif keluarga dan dimensinya yaitu kualitas hidup personal subjektif. Kesadaran dalam masyarakat memiliki pengaruh terhadap kualitas hidup subjektif keluarga dan dimensinya yaitu kualitas hidup sosial subjektif.
\end{abstract}

Kata kunci: kekosmopolitan, kepribadian, kualitas hidup subjektif keluarga, orientasi nilai

\section{If the Personality, Cosmopolitanism, and Value Orientation Determine the Subjective Life Quality of Family?}

\begin{abstract}
Personality, cosmopolitanism, and value orientation can affect the life quality of families who lived in the city. The objective of the research was to analyze the effect of personality, cosmopolitanism, and value orientation on subjective life quality of family in Bogor City, West Java Province. This research used a cross sectional study design and involved 56 families. Data was collected by interview with wife using questionnaire. Furthermore, data was analyzed using Pearson's correlation test and multiple linear regression. The result showed that family value, societal consciousness, and value orientation was correlated significantly with subjective life quality of family and also with two dimension of subjective life quality of family. Value orientation of traditionalism correlated significantly with subjective life quality of family and also with subjective life quality personal. Societal consciousness had an effect on subjective life quality of family and the dimensions of subjective life quality of family, subjective life quality social.
\end{abstract}

Keywords: cosmopolitanism, personality, subjective life quality of family, value orientation

\section{PENDAHULUAN}

Manusia adalah kekayaan bangsa dan sekaligus modal dasar untuk pembangunan. Pembangunan manusia yang sesungguhnya adalah menempatkan manusia sebagai tujuan akhir dari pembangunan dan bukan sebagai alat dari pembangunan. Oleh karena itu, tujuan utama pembangunan adalah menciptakan lingkungan yang memungkinkan masyarakat untuk menikmati hidup sehat, panjang umur, dan menjalankan kehidupan yang produktif.

Salah satu cara mengukur pembangunan manusia adalah dengan cara menggunakan Indeks Pembangunan Manusia (IPM). Secara khusus, IPM mengukur capaian pembangunan manusia berbasis sejumlah komponen dasar kualitas hidup. Indikator IPM merupakan indeks komposit yang mencakup tiga bidang pembangunan manusia yang dianggap sangat mendasar yaitu usia hidup (longevity), pengetahuan (knowledge), dan standar hidup layak (decent living). Selain mengukur kualitas hidup fisik, IPM juga mengukur kualitas hidup nonfisik (intelektualitas) melalui lamanya ratarata penduduk bersekolah, angka melek huruf, dan mempertimbangkan kemampuan ekonomi masyarakat di wilayah tertentu (BPS, 2011).

\begin{tabular}{|c|c|c|}
\hline $\begin{array}{r}\text { Berd } \\
\text { rganizat }\end{array}$ & $\begin{array}{l}\text { definisi } \\
\text { (WHO), }\end{array}$ & $\begin{array}{r}\text { World } \\
\text { kualitas }\end{array}$ \\
\hline
\end{tabular}


menunjukkan persepsi individual dari posisinya dalam konteks kehidupan dan budaya yang sesuai dengan sistem nilai sosial yang berlaku, tujuan personal, harapan, dan concerns of life (Cramer, Torgersen, \& Kringlen, 2004). WHO mengemukakan bahwa terdapat lima domain atau bidang yang dipakai untuk mengukur kualitas hidup, yaitu kesehatan fisik, kesehatan psikologi, keleluasaan dalam beraktivitas, hubungan sosial, dan lingkungan (Silitonga, 2007).

Menurut Park dan Shin (2005), kualitas hidup menggambarkan seberapa jauh rasa kebahagiaan atau kesejahteraan dan kepuasan yang dialami. Perasaan kebahagiaan adalah hedonis atau dimensi afektif dari kualitas hidup dan rasa kepuasan merupakan dimensi kognitif atau kesejahteraan. Kualitas hidup di suatu tempat dapat dianalisis dalam dua bentuk dimensi utama, yaitu dimensi subjektif dan objektif. Dimensi objektif seperti indeks sosial ekonomi pada tingkatan lokal, regional, dan nasional yang dapat digunakan untuk menilai tingkat hidup dan untuk menggambarkan pencapaian dan kegagalan dalam domain tertentu dari kualitas hidup pada suatu tempat. Dimensi subjektif yaitu persepsi kognitif individu atau kepuasan, karena persepsi dapat mengungkapkan evaluasi subjektif dari pengalaman hidup. Kualitas hidup memiliki tujuh domain yaitu layanan kesehatan, pekerjaan, pendidikan, waktu luang, kualitas lingkungan, keuangan domestik, dan keamanan publik (Liao, 2009).

Kualitas hidup dipengaruhi oleh banyak faktor, diantaranya adalah materi, kesehatan fisik, produktivitas, keamanan, komunitas, psikologis, ekonomi, pendidikan, hubungan sosial, lingkungan, kesejahteraan emosi, dan keleluasaan dalam beraktivitas (Khizindar, 2009). Faktor-faktor tersebut dapat berupa kepribadian, kekosmopolitan, dan nilai. Kepribadian dapat didefinisikan sebagai perbedaan karakteristik yang paling dalam pada manusia yang memiliki ciri-ciri unik dan memengaruhi perilaku (Sumarwan, 2011). Kekosmopolitan merupakan keterbukaan seseorang pada informasi yang dapat dilakukan dengan melakukan kunjungan ke daerah lain untuk mendapatkan informasi. Individu yang memiliki kekosmopolitan yang tinggi akan mencari informasi dari luar lingkungannya (Rogers \& Shoemaker, 1971). Individu dengan kekosmopolitan yang tinggi tidak berarti memiliki respon yang tinggi terhadap informasi yang bermanfaat bagi diri sendiri (Murtiyeni, 2002). Orientasi nilai mencerminkan cara seseorang dalam memutuskan untuk meningkatkan kepentingan pribadi atau mengatasi masalah yang lebih mementingkan diri sendiri untuk meningkatkan kesejahteraan orang lain (Liddell \& Davis, 1996, diacu dalam Duncan, 2007).

Penelitian sebelumnya mengungkapkan bahwa kepribadian memiliki hubungan secara tidak langsung dengan kualitas hidup, yang mana kesehatan memiliki kontribusi penting dalam menghubungkan keduanya (Eklund et al., 2010). Penelitian sebelumnya juga meneliti hubungan antara kepuasan hidup dengan nilai seperti materialisme (Ahuvia, 2002). Hasil penelitian sebelumnya menunjukkan bahwa kesejahteraan personal subjektif dipengaruhi oleh orientasi nilai terhadap nilai keluarga dan kesadaran dalam masyarakat. Nilai keluarga yang kuat dan kesadaran dalam masyarakat yang tinggi memiliki kontribusi positif terhadap kepuasan hidup seseorang. Kesejahteraan sosial subjektif dijelaskan secara signifikan oleh orientasi terhadap nilai keluarga, materialisme, dan kesadaran dalam masyarakat. Nilai keluarga dan kesadaran dalam masyarakat berkontribusi positif, sementara materialisme memberikan kontribusi negatif terhadap kepuasan hidup masyarakat Singapura (Tan, Tambyah, \& Kau, 2006). Sirgy et al. (2012) dan Kau et al. (2000) juga mengemukakan bahwa materialisme memiliki pengaruh yang negatif pada kepuasan hidup dan kesejahteraan subjektif.

Berdasarkan pemaparan tersebut, penelitian ini menarik untuk dikaji mengenai kulitas hidup subjektif keluarga di kota dengan beberapa faktor yang memengaruhinya seperti kepribadian, kekosmopolitan, dan orientasi nilai. Penelitian ini bertujuan untuk: (1) menganalisis kepribadian, kekosmopolitan, orientasi nilai, dan kualitas hidup subjektif keluarga di Kota Bogor, (2) menganalisis hubungan antara kepribadian, kekosmopolitan, dan orientasi nilai keluarga dengan kualitas hidup subjektif keluarga di Kota Bogor, dan (3) menganalisis pengaruh kepribadian, kekosmopolitan, dan orientasi nilai keluarga terhadap kualitas hidup subjektif keluarga di Kota Bogor.

\section{METODE}

Desain penelitian ini adalah cross sectional dengan metode survei. Penelitian dilakukan di Kota Bogor, karena Bogor merupakan kota yang memiliki ciri yang kurang lebih sama dengan kota Jakarta. Letaknya yang tidak terlalu jauh dari ibu kota negara berimplikasi pada pesatnya pembangunan serta pertambahan penduduk yang cepat (BPS 
Kota Bogor, 2011). Penelitian dilakukan di Kelurahan Sukasari, Kota Bogor, Provinsi Jawa Barat yang dipilih secara acak. Pengumpulan data penelitian dilakukan pada bulan Juli hingga Agustus 2012 dan Desember 2012 hingga Februari 2013

Populasi penelitian adalah keluarga di Kelurahan Sukasari dengan kepala keluarga berusia 41-60 tahun (dewasa madya) dan keluarga lengkap. Jumlah contoh adalah 100 keluarga dengan responden adalah istri yang bersedia diwawancara. Jumlah responden yang diwawancara adalah 100 istri, namun data yang dapat ditindaklanjuti untuk diolah hanya 56 keluarga.

Pengambilan data dilakukan dengan cara wawancara menggunakan kuesioner penelitian. Kuesioner yang disusun mencakup kepribadian, kekosmopolitan, orientasi nilai, dan kualitas hidup subjektif. Pengukuran variabel kepribadian dan kekosmopolitan mengacu pada Murtiyeni (2002). Kepribadian terdiri atas 16 sifat dan masing-masing sifat diisi berdasarkan kecenderungan sifat responden. Kepribadian diukur dengan sifat yang lebih dominan pada diri responden. Penghitungan kepribadian dilakukan dengan cara menjumlah skor kepribadian sehingga digolongkan menjadi dua tipe, yaitu tipe A atau ekstrovert (41-64) dan tipe B atau introvert (16-40). Kekosmopolitan diukur menggunakan kuesioner tertutup yang menunjukkan frekuensi kunjungan atau perjalanan responden dalam satu tahun. Pengelompokan kekosmopolitan didasarkan pada ketentuan frekuensi sehingga diperoleh total skor antara 0-12, dengan asumsi setiap bulan istri melakukan perjalanan minimal satu kali. Kekosmopolitan dikategorikan menjadi dua berdasarkan interval kelas menjadi dua, yaitu kurang kosmopolit (0-6) dan kosmopolit (7-12).

Orientasi nilai diukur berdasarkan lima dimensi konsep Tan, Tambyah, dan Kau (2006). Dimensi-dimensi yang terdapat pada orientasi nilai adalah nilai keluarga, materialisme, kesadaran dalam masyarakat, kesadaran status, dan tradisionalisme. Pengelompokan orientasi nilai didasarkan pada ketentuan pemberian nilai sehingga diperoleh total skor antara 38-152. Berdasarkan interval kelas, orientasi nilai dikategorikan menjadi tiga, yaitu kurang (38-76), sedang (77-114), dan baik (115-152). Berdasarkan variabel orientasi nilai maka dimensi nilai keluarga dan materialisme memiliki skor 8-32 dengan kategori kurang (816), sedang (17-24), dan baik (25-32). Kesadaran dalam masyarakat memiliki skor 936 dengan kategori kurang (9-18), sedang (19-
27), dan baik (28-36). Kesadaran status memiliki skor 6-24 dengan kategori kurang (612), sedang (13-18), dan baik (19-24). Tradisionalisme memiliki skor 7-28 dengan kategori kurang (7-14), sedang (15-21), dan baik (22-28). Kuesioner orientasi nilai memiliki nilai Cronbach's alpha sebesar 0,610 untuk nilai keluarga, 0,730 untuk materialisme, 0,609 untuk kesadaran dalam masyarakat, 0,345 untuk kesadaran status, dan 0,599 untuk tradisionalisme.

Kualitas hidup subjektif terdiri atas dua dimensi yaitu kualitas hidup personal dan kualitas hidup sosial. Kualitas hidup personal subjektif terdiri atas enam subdimensi yang dikembangkan dari konsep Kau dan Wang (1995), yaitu hubungan dengan anak (sepuluh pernyataan), hubungan dengan orang tua (sembilan pernyataan), hubungan dengan saudara (delapan pernyataan), hubungan dengan pasangan (enam pernyataan), teman (sembilan pernyataan), dan waktu senggang atau rekreasi (sembilan pernyataan). Kuesioner kualitas hidup personal memiliki nilai Cronbach's alpha sebesar 0,604. Masingmasing pernyataan diberi nilai dengan ketentuan: sangat puas (nilai 4), puas (nilai 3), tidak puas (nilai 2), dan sangat tidak puas (nilai 1). Pengelompokan kualitas hidup personal subjektif berdasarkan pada ketentuan pemberian nilai sehingga diperoleh total skor antara 51-204. Berdasarkan interval kelas, kualitas hidup personal dikategorikan menjadi tiga kategori, yaitu kurang sejahtera (51-102), cukup sejahtera (103-153), dan sejahtera (154-204).

Kualitas hidup sosial subjektif terdiri atas sembilan subdimensi yang dikembangkan dari konsep Tan, Tambyah, \& Kau (2006). Subdimensi yang terdapat pada kesejahteraan sosial subjektif meliputi kebersihan kota, transportasi umum, keamanan, pelaksanaan hukum, pendidikan, kesehatan, pelayanan konsumen, peluang karir, dan biaya hidup. Kuesioner kualitas hidup sosial terdiri atas 25 pernyataan. Kuesioner ini memiliki nilai Cronbach's alpha sebesar 0,662. Masingmasing pernyataan diberi nilai dengan ketentuan: sangat setuju (nilai 4), setuju (nilai 3), tidak setuju (nilai 2), dan sangat tidak setuju (nilai 1). Pengelompokan kualitas hidup sosial subjektif berdasarkan pada ketentuan pemberian nilai, sehingga diperoleh total skor antara 25-100. Berdasarkan interval kelas, dikategorikan menjadi tiga, yakni kurang sejahtera (25-50), cukup sejahtera (51-75), dan sejahtera (76-100). 
Analisis yang digunakan dalam penelitian ini adalah uji korelasi Pearson dan uji regresi linier berganda. Uji korelasi Pearson dilakukan untuk menguji hubungan antara variabelvariabel penelitian, yaitu hubungan antara kepribadian, kekosmopolitan, dan orientasi nilai dengan kualitas hidup subjektif keluarga dan dimensinya. Uji regeresi linier berganda digunakan untuk menganalisis pengaruh kepribadian, kekosmopolitan, dan orientasi nilai terhadap kualitas hidup subjektif keluarga dan dimensinya.

\section{HASIL}

\section{Kepribadian}

Kepribadian dikelompokkan menjadi dua kelompok yaitu ekstrovert dan introvert. Lebih dari separuh $(69,6 \%)$ kepribadian responden termasuk dalam kepribadian tipe $A$ atau ekstrovert. Sisanya termasuk dalam kategori B atau introvert $(30,4 \%)$. Artinya, 39 dari 56 responden memiliki ciri-ciri 1) ramah, dominan, pemberani, 2) lunak, mudah setuju, percaya, 3) mandiri, jujur, modern, 4) percaya diri, terkendali, santai, humoris, 5) praktis, perasa, lebih cerdas.

\section{Kekosmopolitan}

Pengelompokan kekosmopolitan dikelompokkan menjadi dua kelompok yang didasarkan pada perhitungan interval. Hampir seluruh responden $(94,6 \%)$ termasuk dalam kategori kurang kosmopolit. Artinya, sebagian besar responden hanya mengunjungi daerah lain dengan frekuensi kurang dari enam kali dalam setahun.

\section{Orientasi Nilai}

Orientasi nilai menekankan pada kebutuhan orang lain dan kebutuhan diri sendiri. Dalam penelitian ini, orientasi nilai diukur melalui 5 dimensi yang masing-masing dimensi terdiri dari beberapa pernyataan dengan skala likert 1 sampai 4 . Masing-masing dimensi dikelompokkan menjadi tiga kelompok, yaitu kurang, sedang, dan baik.

Nilai Keluarga. Dari seluruh dimensi orientasi nilai, hanya dimensi nilai keluarga yang memiliki persentase 100 persen pada kategori nilai keluarga yang baik, sedangkan sisanya berada dibawah 100 persen. Hal ini menunjukkan bahwa seluruh keluarga responden memiliki perhatian yang besar untuk keluarga dan selalu mengutamakan kepentingan keluarga.
Materialisme. Dimensi orientasi nilai yaitu materialisme mencapai tiga perempat $(75 \%)$ dari seluruh keluarga responden yang berada pada kategori sedang, dan sisanya berada pada kategori kurang $(19,6 \%)$ dan baik $(5,4 \%)$. Ini berarti bahwa tiga perempat keluarga responden beranggapan bahwa materi adalah salah satu penunjang kehidupan, tetapi tidak menjadi salah satu faktor yang membuat kehidupan keluarga menjadi bahagia.

Kesadaran dalam masyarakat. Kesadaran dalam masyarakat menunjukkan partisipasi untuk membantu orang lain. Kesadaran dalam masyarakat dalam penelitian ini menujukkan bahwa hampir seluruh (98,2\%) keluarga responden memiliki kesadaran dalam masyarakat yang baik. Artinya, hampir seluruh keluarga responden mengetahui statusnya sebagai mahluk sosial yang berinteraksi dengan orang lain dan berpartisipasi dalam membantu orang lain.

Kesadaran status. Sebagian besar keluarga responden $(89,3 \%)$ memiliki kesadaran status yang termasuk dalam kategori sedang. Hal ini menunjukkan bahwa keluarga responden cukup mengetahui bahwa dengan membeli barang-barang mahal ataupun menunjukkan kekayaan didepan orang lain tidak akan meningkatkan status keluarga dimasyarakat.

Tradisionalisme. Hampir seluruh keluarga responden $(98,2 \%)$ memiliki nilai tradisionalisme yang baik. Artinya, hampir seluruh keluarga responden mempercayai dan melakukan hal-hal yang sesuai dengan budaya.

Secara umum, orientasi nilai keluarga responden termasuk dalam kategori baik $(96,4 \%)$ dan sisanya terdapat pada kategori sedang $(3,6 \%)$ dengan rata-rata 122,68 . Hal ini menujukkan bahwa keluarga responden mengutamakan keluarga, materi bukanlah hal utama yang menjadi tujuan, ikut berpartisipasi untuk membantu orang lain, menyadari bahwa status keluarga tidak berdasarkan materi, dan melaksanakan kehidupan berdasarkan budaya yang berlaku.

\section{Kualitas Hidup Subjektif Keluraga}

Kualitas hidup subjektif keluarga pada penelitian ini diukur melalui dua dimensi, yaitu kualitas hidup personal dan kualitas hidup sosial subjektif. Kualitas hidup personal subjektif diukur dengan menggunakan enam subdimensi yang masing-masing terdiri atas beberapa per-nyataan dengan skala Likert 1 
sampai 4. Total seluruh dimensi dikelompokkan menjadi tiga yaitu kurang sejahtera, cukup sejahtera, dan sejahtera. Hampir seluruh $(98,2 \%)$ responden memiliki kualitas hidup personal subjektif yang berada pada kelompok sejahtera. Artinya, responden merasa puas dan sejahtera mengenai hubungannya dengan orang-orang disekitarnya termasuk teman dan waktu luang serta rekreasi. Lebih dari separuh $(66,1 \%)$ responden memiliki kualitas hidup sosial subjektif pada kategori sejahtera. Sisanya, sebesar 32,1 persen adalah cukup sejahtera dan hanya 1,8 persen tidak sejahtera. Hal ini berarti lebih dari separuh responden merasa puas dan sejahtera dengan kondisi dan fasilitas yang tersedia dilingkungannya. Hampir seluruh responden $(94,6 \%)$ memiliki kualitas hidup subjektif yang berada pada kelompok sejahtera. Artinya, responden merasa puas dan sejahtera mengenai kehidupannya, baik secara personal maupun sosial.

Hubungan kepribadian, Kekosmopolitan, dan Orientasi Nilai dengan Kualitas Hidup Subjektif Keluarga dan Dimensinya

Hasil analisis hubungan antara kepribadian, kekosmopolitan, dan orientasi nilai dengan kualitas hidup subjektif keluarga dan dimensinya (personal dan sosial) dianalisis dengan uji korelasi Pearson. Hasil analisis disajikan pada Tabel 1.

Tabel 1 Koefisien korelasi antara kepribadian, kekosmopolitan, dan orientasi nilai dengan kualitas hidup subjektif keluarga dan dimensinya

\begin{tabular}{lccc}
\hline \multirow{2}{*}{$\begin{array}{l}\text { Variabel } \\
\text { independen }\end{array}$} & $\begin{array}{c}\text { Kualitas } \\
\text { hidup } \\
\text { subjektif } \\
\text { keluarga }\end{array}$ & \multicolumn{2}{c}{$\begin{array}{c}\text { Dimensi kualitas } \\
\text { hidup subjektif } \\
\text { keluarga }\end{array}$} \\
\cline { 3 - 4 } $\begin{array}{l}\text { Kepribadian } \\
\text { Kekosmo- } \\
\text { politan }\end{array}$ & 0,109 & 0,012 & 0,138 \\
$\begin{array}{l}\text { Orientasi } \\
\text { nilai }\end{array}$ & $0,458^{* *}$ & $0,447^{* *}$ & $0,275^{*}$ \\
$\begin{array}{l}\text { Nilai } \\
\text { keluarga }\end{array}$ & $0,497^{* *}$ & $0,418^{* *}$ & $0,351^{* *}$ \\
$\begin{array}{l}\text { Material- } \\
\text { isme }\end{array}$ & $-0,101$ & 0,051 & $-0,175$ \\
$\begin{array}{l}\text { Kesadaran } \\
\text { dalam }\end{array}$ & $0,579^{* *}$ & $0,375^{* *}$ & $0,493^{* *}$ \\
$\begin{array}{l}\text { Masyarakat } \\
\text { Kesadaran } \\
\text { status }\end{array}$ & 0,155 & 0,104 & 0,130 \\
$\begin{array}{l}\text { Tradisional- } \\
\text { isme }\end{array}$ & $0,444^{* *}$ & $0,469^{* *}$ & 0,240 \\
\hline
\end{tabular}

Keterangan:

*Signifikan pada $p \leq 0,05$

**Signifikan pada $p \leq 0,01$
Nilai keluarga memiliki hubungan yang positif signifikan dengan kualitas hidup subjektif keluarga dan dua dimensinya, yaitu kualitas hidup personal dan sosial subjektif. Kesadaran dalam masyarakat memiliki hubungan yang positif signifikan dengan kualitas hidup subjektif keluarga dan dua dimensinya, yaitu kualitas hidup personal dan sosial subjektif. Tradisionalisme memiliki hubungan yang positif signifikan dengan kualitas hidup subjektif keluarga dan dimensinya yaitu kualitas hidup personal subjektif. Orientasi nilai secara keseluruhan memiliki hubungan yang positif signifikan dengan kualitas hidup subjektif keluarga dan dua dimensinya, yaitu kualitas hidup personal dan sosial subjektif. Sementara itu, kualitas hidup juga tidak berhubungan dengan kepribadian dan kekosmopolitan.

Pengaruh Kepribadian, Kekosmopolitan, dan Orientasi Nilai terhadap Kualitas Hidup Subjektif Keluarga dan Dimensinya

Hasil analisis pengaruh kepribadian, kekosmopolitan, dan orientasi nilai terhadap kualitas hidup subjektif keluarga menghasilkan nilai adjusted $R$ square sebesar 0,404 . Artinya, model hanya dapat menjelaskan variabel yang berpengaruh terhadap kualitas hidup subjektif keluarga sebesar 40,4 persen, sedangkan sisanya dijelaskan oleh variabel lain yang tidak diteliti. Dimensi dari variabel orientasi nilai yang memengaruhi kualitas hidup subjektif keluarga adalah kesadaran dalam masyarakat. Kesadaran dalam masyarakat berpengaruh positif signifikan $(\beta=0,462 ; p=0,004)$ terhadap kualitas hidup subjektif keluarga (Tabel 2).

Hasil analisis regresi pengaruh kepribadian, kekosmopolitan, dan orientasi nilai terhadap kesejahteraan personal subjektif menghasilkan nilai adjusted $R$ square sebesar 0,238 . Artinya, model hanya dapat menjelaskan variabel yang berpengaruh terhadap kualitas hidup personal subjektif sebesar 23,8 persen, sedangkan sisanya dijelaskan oleh variabel lain yang tidak diteliti. Penelitian terdahulu mengemukakan bahwa kualitas hidup personal subjektif dipengaruhi oleh nilai keluarga dan kesadaran sosial. Tidak terdapat variabel yang berpengaruh terhadap kualitas hidup personal subjektif. Nilai signifikansi model lebih rendah $(0,004)$ daripada taraf signifikansi sebesar lima persen atau 0,01 maka dapat dinyatakan bahwa terdapat pengaruh secara simultan antara kepribadian, kekosmopolitan, dan orientasi nilai serta dimensinya terhadap kualitas hidup personal subjektif (Tabel 2). 
Tabel 2 Koefisien regresi untuk analisis kepribadian, kekosmopolitan, dan orientasi nilai terhadap kualitas hidup subjektif keluarga

\begin{tabular}{|c|c|c|c|c|c|c|c|c|c|}
\hline \multirow{2}{*}{ Variabel independen } & \multicolumn{3}{|c|}{ Kualitas hidup subjektif } & \multicolumn{3}{|c|}{$\begin{array}{l}\text { Kualitas hidup subjektif } \\
\text { (dimensi personal) }\end{array}$} & \multicolumn{3}{|c|}{$\begin{array}{l}\text { Kualitas hidup subjektif } \\
\text { (dimensi sosial) }\end{array}$} \\
\hline & $B$ & $\beta$ & Sig. & B & $\beta$ & Sig. & B & $\beta$ & Sig. \\
\hline Konstanta & 92,174 & & 0,001 & 88,405 & & 0,000 & 3,769 & & 0,866 \\
\hline Kepribadian & 0,662 & 0,031 & 0,782 & $-1,038$ & $-0,087$ & 0,499 & 1,700 & 0,108 & 0,405 \\
\hline Kekosmopolitan & $-0,843$ & $-0,172$ & 0,206 & $-0,267$ & $-0,090$ & 0,529 & $-0,576$ & $-0,158$ & 0,308 \\
\hline \multicolumn{10}{|l|}{ Orientasi nilai } \\
\hline - Nilai keluarga & 1,353 & 0,239 & 0,077 & 0,931 & 0,293 & 0,058 & 0,422 & 0,100 & 0,510 \\
\hline - Materialisme & $-0,146$ & $-0,051$ & 0,690 & 0,222 & 0,138 & 0,344 & $-0,368$ & $-0,173$ & 0,239 \\
\hline $\begin{array}{l}\text { - Kesadaran dalam } \\
\text { masyarakat }\end{array}$ & $2,333^{\star *}$ & $0,462^{* *}$ & $0,004^{* *}$ & 0,608 & 0,213 & 0,226 & $1,724^{*}$ & $0,459^{*}$ & $0,012^{*}$ \\
\hline - Kesadaran status & 0,939 & 0,158 & 0,188 & 0,121 & 0,036 & 0,788 & 0,818 & 0,185 & 0,177 \\
\hline - Tradisionalisme & 0,956 & 0,138 & 0,308 & 0,992 & 0,254 & 0,101 & $-0,036$ & $-0,007$ & 0,964 \\
\hline Adjusted $R$ Square & & 0,404 & & & 0,238 & & & 0,222 & \\
\hline Signifikansi & & $0,000^{* *}$ & & & $0,004^{* *}$ & & & $0,007^{* *}$ & \\
\hline
\end{tabular}

Keterangan: * Signifikan pada $p<0,01$

Tabel 2 juga menyajikan hasil analisis pengaruh kepribadian, kekosmopolitan, dan orientasi nilai terhadap kualitas hidup sosial subjektif menghasilkan nilai adjusted $R$ square sebesar 0,222. Hal ini berarti bahwa model hanya dapat menjelaskan variabel yang berpengaruh terhadap kualitas hidup sosial subjektif sebesar 22,2 persen, sedangkan sisanya dijelaskan oleh variabel lain yang tidak diteliti. Penelitian terdahulu menemukan bahwa ke-sejahteraan sosial subjektif dipengaruhi secara signifikan oleh nilai keluarga, materialisme, dan kesadaran sosial. Dimensi variabel orientasi nilai yang memengaruhi kualitas hidup sosial subjektif adalah kesadaran dalam masyarakat. Kesadaran dalam masyarakat berpengaruh positif signifikan $(\beta=$ $0,459 ; p=0,012)$ terhadap kualitas hidup sosial subjektif.

\section{PEMBAHASAN}

Hasil penelitian ini menunjukkan bahwa tidak terdapat hubungan yang signifikan antara kepribadian dengan kualitas hidup subjektif dan dua dimensinya. Padahal menurut Wrosch dan Scheier (2003) dan Dobewall et al. (2013) bahwa kualitas hidup seseorang bergantung pada kepribadiannya. Hal ini diduga bahwa kepribadian seseorang tidak berhubungan langsung dengan kualitas hidup sebagaimana dinyatakan oleh Eklund et al. (2010) bahwa keterkaitan antara kepribadian dengan kualitas hidup perlu dimoderasi oleh variabel lain, salah satunya adalah kesehatan.

Hasil penelitian juga menunjukkan bahwa tidak terdapat hubungan yang signifikan antara kosmopolitan dengan kualitas hidup subjektif. Padahal menurut individu dengan mobilitas yang tinggi akan membuat individu tersebut memperoleh informasi-informasi baru yang bermanfaat untuk meningkatkan kualitas hidup subjektif keluarganya. Hal ini diduga karena seseorang dengan kekosmopolitan yang tinggi tidak berarti memiliki respon yang tinggi terhadap informasi yang bermanfaat bagi dirinya sendiri (Murtiyeni, 2002). Selain itu, walaupun informasi yang diterimanya semakin banyak, informasi tersebut tidak selalu dapat meningkatkan kualitas hidup subjektif orang tersebut, bahkan bisa jadi menurunkan kepuasannya terhadap kehidupannya. Dugaan lainnya adalah bahwa orang yang kosmopolit tidak selalu memaknai setiap informasi baru yang diterimanya untuk meningkatkan standar hidupnya. Seseorang yang mengunjungi daerah dengan tingkat modernitas di atas daerah asalnya, cenderung akan kurang puas dengan kualitas hidup di daerah asalnya dan begitupun sebaliknya. Akan tetapi, keterbatasan dari penelitian ini adalah tidak melihat karakteristik daerah tujuan dari kunjungan responden.

Penelitian ini juga menunjukkan nilai keluarga memiliki hubungan yang positif signifikan dengan kualitas hidup subjektif keluarga dan dua dimensinya, yaitu kualitas hidup personal dan sosial subjektif. Semakin memiliki perhatian yang besar untuk keluarga dan selalu mengutamakan kepentingan keluarga maka responden semakin merasa puas dan sejahtera mengenai kehidupannya secara keseluruhan maupun secara personal dan sosial. Hal ini sesuai dengan yang telah dikemukakan oleh Tan, Tambyah, dan Kau (2006) bahwa memiliki orientasi pada keluarga dan yang didasarkan pada nilai-nilai yang memelihara ikatan keluarga yang kuat akan membuat kehidupan menjadi bahagia. Yao, 
Cheng, dan Cheng (2008) juga mengungkapkan bahwa salah satu prioritas nilai yang paling penting adalah keluarga, yaitu dengan menghabiskan waktu bersama keluarga dan membesarkan anak-anak.

Selain itu, dalam penelitian ini ditemukan juga bahwa kesadaran dalam masyarakat memiliki hubungan yang positif signifikan dengan kualitas hidup subjektif keluarga dan dua dimensinya yaitu kualitas hidup personal dan sosial subjektif. Selain itu kesadaran dalam masyarakat juga memiliki pengaruh terhadap kualitas hidup subjektif keluarga dan dimensinya yaitu kualitas hidup sosial subjektif. Semakin tinggi kesadaran dalam masyarakat responden maka responden semakin merasa puas dan sejahtera mengenai hubungannya dengan orang-orang sekitarnya termasuk teman dan waktu luang serta rekreasi, merasa puas dan sejahtera dengan kondisi dan fasilitas yang tersedia dilingkungannya, dan merasa puas dan sejahtera dengan kehidupannya secara keseluruhan. Hal ini sesuai dengan Tan, Tambyah, dan Kau (2006) bahwa masyarakat yang peduli dengan lingkungan sosialnya serta terlibat dalam membantu orang lain akan menimbulkan rasa sejahtera. Hellevik (2003) mengemukakan bahwa individu yang bersedia memberikan kontribusi yang lebih kepada masyarakat dan menunjukkan empati yang tinggi kepada orang lain merasa lebih bahagia. Orientasi terhadap tradisionalisme dalam penelitian ini menunjukkan hubungan yang positif signifikan dengan kualitas hidup subjektif keluarga dan dimensinya yaitu kualitas hidup personal subjektif. Responden yang semakin mempercayai dan melakukan hal-hal yang sesuai dengan budaya semakin merasa puas dan sejahtera dengan kehidupan yang dijalaninya. Hal ini diduga karena individu yang mempercayai dan melakukan sesuatu berdasarkan nilai-nilai yang sesuai dengan tradisi dan budaya yang telah diajarkan oleh generasi sebelumnya, merasa puas dan sejahtera bila dapat menerapkannya dalam kehidupannya saat ini. Dengan kata lain, mengamalkan nilainilai budaya yang telah diperolehnya sejak dulu. Tan, Tambyah, dan Kau (2006) mengemukakan bahwa masyarakat yang memegang kepercayaan tradisional menjadi enggan untuk mencoba cara-cara atau ide baru untuk melakukan sesuatu. Hellevik (2003) mengemukakan bahwa tradisionalisme memiliki hubungan dengan kebahagiaan walaupun hubungan tersebut lemah.

Orientasi nilai secara keseluruhan dalam penelitian ini menunjukkan hubungan yang positif signifikan dengan kualitas hidup subjektif keluarga dan dimensinya yaitu kualitas hidup personal dan sosial subjetif. Semakin baik orientasi nilai responden maka responden semakin merasa puas dan sejahtera mengenai hubungannya dengan orang-orang sekitarnya termasuk teman dan waktu luang serta rekreasi, merasa puas dan sejahtera dengan kondisi dan fasilitas yang tersedia di lingkungannya, dan merasa puas dan sejahtera dengan kehidupannya secara keseluruhan. Tiga dari lima dimensi variabel orientasi nilai yaitu nilai keluarga, kesadaran dalam masyarakat, dan tradisionalisme memiliki hubungan yang positif signifikan dengan kualitas hidup subjektif keluarga dan dimensinya yaitu kualitas hidup personal dan sosial subjektif. Oleh karena itu, jika orientasi nilai secara keseluruhan dihubungkan, maka terdapat hubungan yang positif signifikan antara orintasi nilai dengan kualitas hidup personal dan sosial subjektif, maupun dengan kualitas hidup subjektif keluarga. Tan, Tambyah, dan Kau (2006) mengemukakan bahwa dua dari lima dimensi orientasi nilai memiliki hubungan dan pengaruh hanya terhadap kesejahteraan personal subjektif. Namun, hanya hubungan dan pengaruh mengenai orientasi nilai setiap dimensi dan bukanlah orientasi nilai secara keseluruhan.

Secara keseluruhan, kualitas hidup subjektif keluarga pada penelitian ini dipengaruhi secara signifikan oleh kesadaran dalam masyarakat. Hasil ini bertentangan dengan penelitian-penelitian terdahulu yang menyatakan bahwa kepribadian memiliki hubungan dan pengaruh terhadap kesejahteraan, kepuasan, dan kualitas hidup walaupun tidak secara langsung (Eklund et al., 2010; Wrosch \& Scheier, 2003). Hal ini diduga karena data yang diperoleh mengenai kepribadian dan kekosmopolitan responden cenderung tidak bervariasi. Yao, Cheng, dan Cheng (2008) mengemukakan bahwa variabel subjektif seperti kepuasan, prioritas nilai, harga diri, dan kepercayaan interpersonal lebih kuat dalam memprediksi kualitas hidup secara keseluruhan dibandingkan dengan variabel objektif, seperti demografi. Shu dan Zhu (2009) mengemukakan bahwa kepuasan dengan kehidupan pada lingkungan antarpersonal merupakan prediktor yang kuat pada kualitas hidup subjektif di China. Secara literatur, prediktor yang paling kuat untuk memprediksi kualitas hidup secara keseluruhan adalah kepuasan per bagian hidup, bukan kepuasan secara struktural (Drews, 1990). Oleh karena itu, pada penelitian ini juga variabel kepribadian dan kekosmopolitan tidak memiliki pengaruh terhadap 
kualitas hidup secara keseluruhan maupun per bagian hidup.

\section{SIMPULAN DAN SARAN}

Kualitas hidup subjektif keluarga dan dua dimensinya, yaitu personal dan sosial subjektif berada pada kategori sejahtera. Kepribadian dan kekosmopolitan tidak berpengaruh signifikan terhadap kualitas hidup subjektif secara umum maupjun berdasarkan dimensinya (personal dan sosial). Kualitas hidup subjektif keluarga berhubungan dengan orientasi nilai terutama pada nilai keluarga, kesadaran dalam masyarakat, dan tradisionallisme. Kesadaran dalam masyarakat dapat meningkatkan kualitas hidup subjektif keluarga. Berdasarkan dimensinya, dimensi kualitas hidup subjektif terdiri atas dimensi personal dan sosial. Kualitas hidup personal berhubungan signifikan dengan orientasi nilai terutama pada nilai keluarga, kesadaran dalam masyarakat, dan tradisionallisme. Akan tetapi, orientasi nilai tidak berpengaruh signifikan pada kualitas hidup subjektif dimensi personal. Kualitas hidup pada dimensi sosial juga berhubungan dengan orientasi nilai terutama pada nilai keluarga dan kesadaran pada masyarakat. Kualitas hidup subjektif pada dimensi sosial juga meningkat dengan meningkatnya kesadaran dalam masyarakat.

Orientasi nilai terhadap nilai keluarga menunjukkan bahwa nilai keluarga atau memiliki perhatian yang besar untuk keluarga dan selalu mengutamakan kepentingan keluarga memiliki hubungan dengan kualitas hidup subjektif keluarga. Oleh karena itu, pemerintah diharapkan dapat lebih mengenalkan program BKKBN (Badan Kependudukan dan Keluarga Berencana Nasional) yaitu PPKS (Pusat Pelayanan Keluarga Sejahtera) kepada masyarakat karena dapat membantu permasalahan sosial rumah tangga, kesehatan reproduksi, dan hal terkait lainnya.

\section{DAFTAR PUSTAKA}

Ahuvia, A. C. (2002). Individualism/collectivism and culture of happiness: A theoretical conjecture on the relationship between consumption, culture, and subjective wellbeing at the national level. Journal of Happiness Studies, 3, 23-26.

[BKKBN] Badan Koordinasi Keluarga Berencana Nasional. (1998). Opini pembangunan keluarga sejahtera. Jakarta, ID: BKKBN.
[BPS] Badan Pusat Statistik Kota Bogor. (2011). Indeks pembangunan manusia Kota Bogor tahun 2011. Diambil dari http://bogorkota.bps.go.id/New\%20Publika si/ipm2011/index.html. [Diunduh pada 25 Maret 2012].

Cramer, V., Torgersen, S., \& Kringlen, E. (2004). Quality of life in a city. The effect of population density. E-journal of Social Indicators Research.

Dobewall, H., Realo, A., Allik, J., Esko, T., \& Metspalu, A. (2013). Self-other agree-ment in happiness and life-satisfaction: The role of personality traits. Social Indicator Research, 114, 479-492. doi: 10.1007/ s11205-012-0157-y.

Drews, D. H. (1990). Social position, value orientation, and perceived quality of life. $E$ journal of Dissertations and Theses. Diambil dari http://search.proquest.com/ docview/303873984 ?accountid $=32819$. [Diunduh pada 11 Juli 2012].

Duncan, T. B. (2007). Adult attachment and value orientation in marriage. E-journal of Dissertations and Theses. Diambil dari http://search.proquest.com/docview/30472 1769? accountid=32819. [Diunduh pada 5 Mei 2012].

Eklund, M., Backstrom, M., Lissner, L., Bjorkelund., \& Sonn, U. (2010). Daily activeties mediate the relationship between personality and quality of life in middleaged women. Quality of Life Research, 19, 1477-1486. doi: 10.1007/s11136-010-971 1-8.

Hellevik, O. (2003). Economy, values, and happiness in Norway. Journal of Happiness Studies, 4, 243-283.

Kau, A. K., Jung, K., Jiuan, T. S., \& Wirtz, J. (2000). The influence of materialistic inclination on values, life satisfaction, and aspirations: An empirical analysis. Social Indicators Research, 49, 317-333.

Kau, A. K., \& Wang, S. H. (1995). Assessing quality of life in Singapore: An exploratory study. Social Indicators Research, 35, 7191.

Khizindar, T. M. (2009). Quality of life in developing countries: An empirical investigation. The Journal of American Academy of Business, 14(2), 162-170.

Liao, P. S. (2009). Parallels between objective indicators and subjective perceptions of quality of life. A study of metropolitan and country areas in Taiwan. E-journal of social 
Indicators Research.

Murtiyeni. (2002). Respon peternak sapi perah terhadap sumber informasi teknologi peternakan (Kasus di Kecamatan Cibungbulang, Pamijahan, dan Cisarua, Kabupaten Bogor, Jawa Barat) (Tesis). Sekolah Pascasarjana, Institut Pertanian Bogor, Bogor.

Park, C. M., \& Shin, D. C. (2005). Perceptions of life quality among the Korean mass public. Unraveling their dynamics and standards. E-jounal of Social Indicators Research.

Rogers, E. M., \& Shoemaker, F. F. (1971). Communication of innovations: A Crosscultural approach 2nd ed. New York, US: Free Press.

Shu, X., \& Zhu, Y. (2009). The quality of life in China. E-journal of Social Indicators Research, 92, 191-225. USA. Diambil dari http://search.proquest.com/docview/ 197647868? accountid=32819. [Diunduh pada 11 Juli 2012].

Silitonga, R. (2007). Faktor-faktor yang berhubungan dengan kualitas hidup penderita penyakit Parkinson di poliklinik saraf rumah sakit DR. Kariadi (Tesis).
Sekolah Pascasarjana, Universitas Diponegoro, Semarang.

Sirgy, M. J., Eda, G. A., Webb, D., Cicic, M., Husic, M., Ekici, A., Herrmann, A, Hegazy I, Lee D. J., \& Johar, J. S. (2012). Linking advertising, materialism, and life satisfaction. Social Indicator Research, 107, 79-101. doi: 10.1007/s11205-0119829-2.

Sumarwan, U. (2011). Perilaku Konsumen, Teori dan Penerapannya dalam Pemasaran. Bogor, ID: Ghalia Indonesia.

Tan, S. J., Tambyah., S. K, \& Kau., A. K. (2006). The influence of value orien-tations and demographics on quality of life perceptions. Evidence from a national survey of Singaporeans. Social Indicators Research, 78(1), 33-59. doi: 10.1007/s11205-005-7158-z.

Wrosch, C., \& Scheier, M.F. (2003). Personality and quality of life: The importance of optimism and goal adjustment. Quality of Life Research, 12(1), 59-72.

Yao, G., Cheng, Y. P., \& Cheng, C. P. (2008). The quality of life in Taiwan. Social Indicators Research, 92, 377-404. doi:10.1007/s11205-008-9353-1. 